\title{
Creativity: How to Nurture it, and Get it Back
}

\section{Christina Luconi (Rapid7)}

\author{
KEYWORDS: Entrepreneurship, Innovation, \\ Management, Organization, Leadership.
}

From Elon Musk to Richard Branson to Steve Jobs, entrepreneurs are creative visionaries, able to see possibilities that have not been seen before. But fulfilling that vision also requires left-brain pragmatism and analytical skills. How can entrepreneurs stay in touch with their creative side as they grapple with the pressures of launching and running a business?

The good news is that creativity lives within all of us, not just the artistic geniuses or the market disrupters. It's our ability to tap into it - and to continue to nurture it -that makes people true creatives.

Creativity encompasses several attributes. As an entrepreneur, challenge yourself to understand what they are and whether you have them. If you recognize yourself, you already have an advantage. If you feel you are lacking, take heart: these attributes can be nurtured.

Courage -- Creative people all have the courage to take on big challenges and risk failure. They will tinker and experiment to find ways something will work - or not work - until they figure it out. They don't wait for people to tell them; they lead to find their answer.

Curiosity -- Creative people are always asking questions. They seek to gain understanding, and put in the effort to learn everything they can about something works. They can then sort through the clutter of ideas and information and identify hidden meaning or new ways to look at that information. I think of this as being able to "turn the puzzle upside down." By looking at a problem from a different vantage point, they are able to see fresh perspective.

Intuition -- Data be damned...if creative people feel passionately about it, they will power forward to make their decisions and produce ideas. That being said, they won't stop until they have given their best. They have high standards and always believe they can make something better.
Expressive -- They put in a piece of themselves. By being expressive and sharing how they think and feel, they are being themselves. People typically respond to real, and honest. It's not just interesting, but it can also be pretty influential.

A passion for problems. Creative people take on each big problem without an obvious answer with joy. If affords them the opportunity to learn something new and produce something remarkable when solved.

These five attributes can be developed; one does not to be an avant-garde artist or designer to be considered creative. And while I know many of these are not common traits held in everyone, they aren't difficult to build.

Here's how:

Step out of your comfort zone. Often times, we entrepreneurs will follow routines to keep our otherwise chaotic lives in order. In the salad days of building a business, being able to control something is often a comfort. And yet, too much comfort causes us to stagnate and dulls our creativity. So go eat lunch with someone new. Take a different route home from work. Listen to a podcast during your commute you wouldn't normally tune in to. The point is to find small opportunities to look at and experience the world differently. By removing yourself from the mundane and redundant, you open yourself to seeing things differently.

Find kindred spirits. Meet-ups have become increasingly popular in the start up community, allowing informal gatherings to share and learn from one another.

\section{Assemble a thinking team of diverse points of view. If you know, for example, you are a realist who look for data and facts, add a visionary who likes to think big and a problem solver to the mix. By bouncing your ideas off of each other, you might find your original}


idea takes a broader, more innovative path.

Of course for the haggard entrepreneur who is likely already burning the candle at both ends, this seems a daunting task to add to the never-ending to-do list. And yet, it's vital to the success and health of your business. Instead, don't think of it as a task; think of it as a mindset. By weaving different ways of thinking and approaching solutions into your everyday work, you have increased your ability to move far past your initial brilliant idea. Whether you fancy yourself naturally creative or not, any entrepreneur has the ability to supplement his or her approach. Whether it be through partnering with other diverse, complementary thinkers, exposing yourself to other learning opportunities, or even simply pushing yourself to see a problem through a new lens, you've just made yourself decidedly more creative.

Creativity lies within us all, if we are bold enough to go after it. Time to go turn the puzzle upside down and embrace a more innovative way of thinking. 